\title{
First record of louse fly Pseudolyncbia garzettae Rondani, 1879 (Diptera: Hippoboscidae) in East Europe
}

\section{Первая находка мухи-кровососки Pseudolynchia garzettae Rondani, 1879 (Diptera: Hippoboscidae) в Восточной Европе}

\author{
E.P. Nartshuk ${ }^{1}$, A.V. Matyukhin ${ }^{2}$, A.V. Zabashta ${ }^{3}$, M.V. Zabashta ${ }^{3}$ \\ Э.П. Нарчук ${ }^{1}$, А.В. Матюхин ${ }^{2}$, А.В. Забашта ${ }^{3}$, М.В. Забашта ${ }^{3}$
}

\footnotetext{
${ }^{1}$ Zoological institute of Russian Academy of Sciences, Universitetskaya nab. 1, St. Petersburg 199034, Russia. E-mail: chlorops@zin.ru

${ }^{2}$ A.N. Severtsov Institute of Ecology and Evolution, Russian Academy of Sciences. Leninsky pr. 33, Moscow 119071, Russia. E-mail: amatyukhin53@mail.ru

${ }^{3}$ The Federal Government Health Institution «Rostov-on-Don Plague Control Research Institute», M. Gorky st. 117/40, Rostov-on-Don 344002. E-mail: zabashta68@mail.ru; E-mail: zabashta79@mail.ru

Зоологический институт Российской Академии наук. Университетская наб. 1, С.-Петербург 199034, Россия.

${ }^{2}$ Институт проблем экологии и эволюции Российской Академии наук. Ленинский пр. 33, Москва 119071, Россия.

${ }^{3}$ Ростовский-на-Дону противочумный институт Роспотребнадзора, ул. М.Горького 117/40, Ростов-на-Дону 344002, Россия.
}

KEYWORDS: Diptera, Hippoboscidae, Pseudolynchia, new records, Russia, Ukraine.

КЛЮЧЕВЫЕ СЛОВА: Diptera, Hippoboscidae, Pseudolynchia, новые находки, Россия, Украина.

ABSTRACT. A review of records of louse flies Pseudolynchia garzettae (Rondani, 1879) in the Palaearctic Region is presented. The first records of this species in Eastern Europe: Russia (Rostov-on-Don) and Ukraine (Kirovograd Province) are given.

РЕЗЮМЕ. Дан обзор находок мухи-кровососки Pseudolynchia garzettae (Rondani, 1879) в Палеарктике. Впервые описаны две находки в Восточной Европе: Ростов на Дону (Россия) и Кировоградская обл. (Украине).

Louse flies (Diptera: Hippoboscidae) are obligate blood-sucking ectoparasites of birds and mammals. The family contains more 210 species in 22 genera, distributed all over the world except Antarctica. The most species inhabit in tropics of both Hemispheres. In the Palearctic Region occur 55 species and 3 subspecies in 12 genera [Soós, Hůrka, 1986]. Hippoboscidae of fauna of former USSR were studied by Doszhanov [2003], but mainly on material from Kazakhstan, and distribution of louse flies on the territory of Russia has been pour known and need further studied in some detail. It is particularly important for species living on birds. Nearly all ornithophilous Hippoboscidae are polyxenous species and are parasites of birds from different families. Louse fly can lives on a bird during one-fourth months, and with migrant bird can move to any part of world and change their host on new places, move to other species including resident birds. Hippoboscidae damage birds at once as bloodsuckers and as vectors of pathogenic organisms of different nature. Birds and their ectoparasitic Arthropoda including Hippoboscidae are important link in the complex of transmissive diseases caused by viruses, including West Nile virus, rickets and bacteria [Pavlovsky, Tokarevich, 1966; Balashov, 1982]. DNA of Bacillus burgdorferi s.l. genospecies of $B$. afzelii and Borrelia sp. were found in louseflies Icosta ardea (Macquart, 1835), Pseudolynchia canariensis (Macquart, 1840), and Ornithomyia avicularia (Linnaeus, 1758) [Zabashta et al., 2017a, b]. Most ornithophilous species of Hippoboscidae are fully winged and good flyers, have many birds as host and may transfer pathogenic organism from one bird to another [Baker, 1956, 1967]. Some pathogenic organisms develop in the body of louse-flies and can attack birds [Farajollahi et al., 2005; Zabashta et al., 2017a, b].

Pseudolynchia garzettae (Rondani, 1879)

= Olfersia rufipes Macquart, 1847 (partim).

= Pseudolynchia fradeorum Tendeiro, 1951.

MATERIAL. 1 우 - Ukraine, fly was taken not on bird, by net in garden, 16.V.1899, leg. A.O. Graftio, det. Ya. D. Kirshenblat (collection of Zoological Museum, Moscow State University). A.O. Graftio made the map of locality, where he collected insects in 1899, and it permits us to determine exact coordinates $48^{\circ} 13.2133^{\prime} \mathrm{N}$, $32^{\circ} 50.2403^{\prime}$ E (selo Veselye Bokovenki, Dolinsky rayon Kirovogradskoi oblasti); $10^{7}, 3$ 우 — Russia, Rostov/Don (47⒔8812' N, $39^{\circ} 43.39682^{\prime}$ E), 15.V.2017, on five specimens of Caprimulgus europaeus Linnaeus, 1758 , leg. A.V. Zabashta $\left(1 \mathrm{O}^{\text {t7 }}\right.$ and 2 우 — in the collection of Zoological institute of Russian Academy of Sciences in St. Petersburg; 2 +P — in the collection of A.V. Zabashta.

How to cite this article: Nartshuk E.P., Matyukhin A.V., Zabashta A.V., Zabashta M.V. 2019. First record of louse fly Pseudolynchia garzettae Rondani, 1879 (Diptera: Hippoboscidae) in East Europe // Russian Entomol. J. Vol.28. No.1. P.91-92. doi: 10.15298/rusentj.28.1.16 
NOTE. Pseudolynchia garzettae (Rondani, 1879) was described from Italy, but the main range is in Africa south of Sahara (Sierra Leone, Cameroon, Sudan, Uganda, Tanzania, Mozambique, Democratic Republic of Congo, Nigeria, Zimbabwe) and in Asia (Thailand, China (Taiwan), Philippines). The species is repeatedly brought by migrant birds from Africa to southern Europe and from Asia to Kazakhstan and Kyrgyzstan. Rare records are known in Egypt, Cyprus, southwestern Europe, Kazakhstan, Kyrgyzstan [McClure et al., 1973; Doszhanov, 2003]. As host are normally known birds of families Strigidae and Caprimulgidae, especially Caprimulgus affinis Hornsfeld, 1821 and C. macrurus Hornsfeld, 1821 [McClure et al., 1973]. Doszhanov [2003] found flies also on Passer indicus Jardine et Selby, 1831, P. hispaniolensis (Temmnick, 1820), Burhinus oedicnemus (Linnaeus, 1758), Oriolus oriolus (Linnaeus, 1758), Accipiter nisus (Linnaeus, 1758), Streptopelia orientalis (Latham, 1790) and Caprimulgus europaeus in Kazakhstan.

The species is rare in Western Europe and was found as one-two specimens in a few localities [Theodor, Oldroyd, 1964]: Italy, Insubria (= Varese), bird host unknown (Rondani, 1879); France, Camargue: Bouches-du-Rhonex on Otus scopus (Linnaeus, 1758), one specimen; Switzerland, Mt. Saléve vic. Genéva on Caprimulgus europaeus, one specimen; Cyprus - some specimens on Athene noctua (Scopoli, 1769). These records need special attention as birds are residents, not migrants.

In Kazakhstan and Kyrgyzstan Pseudolynchia garzettae is also rare and found only on migrant birds [Doszhanov, 2003].

In Eastern Europe the species was never recorded.

P. garzettae is polyxenous species, but Caprimulgus europaeus and other species of the genus Caprimulgus Linnaeus, 1758 are favorite bird-hosts. Flies can move to resident birds

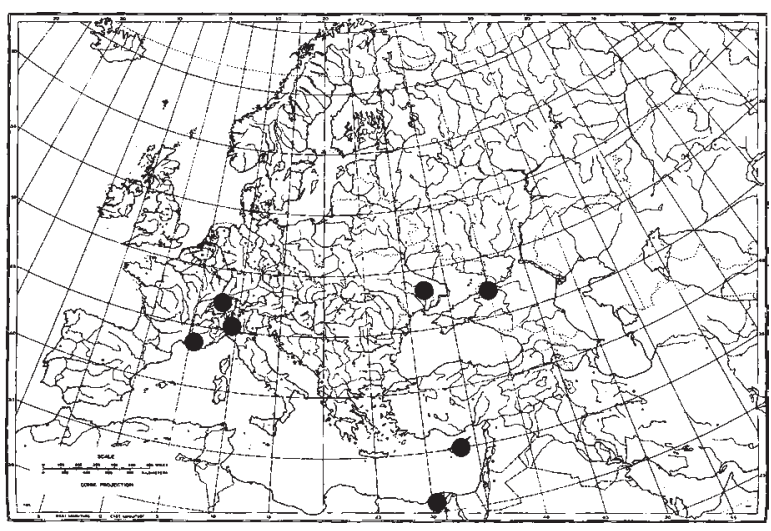

Map. Records of Pseudolynchia garzettae in western Palearctic. Карта. находки Pseudolynchia garzettae в западной Палеарктике. of different families in new localities. All known records of $P$. garzettae in western Palearctic are mapped (Map).

Acknowledgements. The study was performed in the frames of the state research project AAAA-A19$119020690082-8$, and supported by the Presidium RAS program no.41 "Biodiversity of natural systems and biological sources of Russia". Authors wish to express their thanks A.L. Ozerov (Zoological Museum of Moscow State University) for possibility to work with Hippoboscidae collection and to V.M. Loskot (Zoological institute of RAS, St. Petersburg) for consultations on birds.

\section{References}

Baker J.R. 1956. Studies on Trypanosoma avium Danilevsky, 1885. II. Transmission by Ornithomyia avicularia // Journal of Parasitology. Vol.46. P.321-334.

Baker J.R. 1967. A review of the role played by the Hippoboscidae (Diptera) as vectors of endoparasites // Journal of Parasitology. Vol.53. P.412-418.

Balashov Yu.S. 1982. [Parasito-host associations in Arthropoda with Vertebrata]. Leningrad: Nauka. 313 pp. [In Russian]

Doszhanov T.N. 2003. [Louse-flies (Diptera, Hippoboscidae) of The Palearctic Region]. Almaty. 277 pp. [In Russian]

Farajollahi A., Cranes V.J., Nickerson D., Bryant P., Wolf B., Glaser F., Andrea T.G. 2005. Detection of West Nile virus RNA from the louse fly Icosta americana (Diptera: Hippoboscidae) // Journal of the American Mosquito Control Association. Vol.21. No.4. P.474-476.

McClure H.E., Ratanaworabhan N., Emerson K.C., Hoogstaal H., Nadchatran N., Kwanguen P., Atyeo W.T., Maa T.C., Wilson N., Wayupong L. 1973. Some ectoparasites of the birds of Asia. Bangkok: Applied Scientific Corporation of Thailand. 219 pp.

Pavlovsky E.N., Tokarevich K.N. 1966. [Birds and inflectional pathology of men]. Leningrad: Medizina. 227 pp. [In Russian]

Rondani C. 1879. Hippoboscita italicain familiaset genera distribute // Bullettino della Società Entomologica Italiana. Vol.11. P.3-28.

Soós A., Hůrka K. 1986. Family Hippoboscidae. In: Soós Á., L. Papp (Eds). Catalogue of Palearctic Diptera. Vol.11. ScatophagidaeHypodermatidae. Akadémiai Budapest: Kiadó. P.215-226.

Theodor O., Oldroyd H. 1964. Hippoboscidae // E. Lindner (Ed.) Die Fliegen der Palaearktischen Region. Stuttgart. Bd.12. S.1-70.

Zabashta M.V., Pichurina L.N., Savchenko A.P., Romanova L.V., Matyukhin A.V., Zabashta A.V. 2017a. [Specific of circulation of pathogens $P$. borellia on the South of Russia] // Materialy II vserossiyskoi konferencii 5-6 aprelya 2017. Aktualnye problemy bolesney obshchik dlya cheloveka i zhivotnykh. Stavropol. P.145-147 [in Russian].

Zabashta M.V., Pichurina L.N., Matyukhin A.V., Savchenko A.P., Romanova L.V., Zabashta A.V. 2017b.[The epizootological importance of the numerous species of bloodsucking flies (Diptera: Hippoboscidae) of the Western Ciscaucasia] // XV c'ezd Russkogo entomologicheskogo obshchestva. Novosibirsk, 31 iyulya-7 avgusta 2017. Materialy c'ezda. Novosibirsk. P.191-193 [in Russian]. 